\title{
MONGINBALU KONBULAN: SEJARAH DAN NILAI TRADISI MANDI PUASA SECARA MASSAL DALAM MASYARAKAT MUSLIM BOLAANG MONGONDOW
}

\author{
THE MONGINBALU KONBULAN: HISTORY AND VALUE \\ OF FASTING BATH TRADITION EN MASSE IN MUSLIM \\ SOCIETY OF BOLAANG MONGONDOW
}

\author{
Moh. Rivaldi Abdul \\ Universitas Islam Negeri Sunan Kalijaga Yogyakarta, Indonesia \\ rivaldiabdul2@gmail.com
}

DOI: $10.31291 /$ jlk.v19i1.892

Diterima: 01 Februari 2021; Direvisi: 16 Juni 2021; Diterbitkan: 30 Juni 2021

\begin{abstract}
This article examines the Monginbalu Konbulan tradition, which is one of the Islamic traditions of the Bolaang Mongondow Muslim community. This tradition has long been carried out as part of welcoming the month of Ramadan. Historical, anthropological, and sociological approaches are used to understand the practice of Monginbalu Konbulan, and explore its history and values. This article shows that the Monginbalu Konbulan is a mass fasting bath tradition carried out by the Muslim community of Bolaang Mongondow on the last afternoon of the month of Shaban. The mass bathing procession was led by a jiow who would splash water on people. This has been going on for a long time, and the birth of the mass fasting bath tradition is the answer to the needs of the Bolaang Mongondow Muslim community who want to carry out the Ramadan fasting bath. In addition, the implementation of the Monginbalu Konbulan tradition is also full of value, thus making it urgent to be preserved as a peculiarity of the Nusantara Islamic tradition in the Bolaang Mongondow Muslim community.
\end{abstract}

Keywords: Welcoming Ramadan, Bathing Together, Bolaang Mongondow Tradition, Nusantara Islamic Tradition 


\begin{abstract}
ABSTRAK
Artikel ini mengkaji tradisi Monginbalu Konbulan yang merupakan salah satu tradisi Islam masyarakat muslim Bolaang Mongondow. Tradisi tersebut sudah lama dilakukan sebagai bagian menyambut bulan Ramadan. Pendekatan sejarah, antropologi, dan sosiologi digunakan untuk memahami praktik Monginbalu Konbulan, dan menggali sejarah serta nilai-nilainya. Artikel ini menunjukkan bahwa Monginbalu Konbulan merupakan tradisi mandi puasa secara massal yang dilakukan oleh masyarakat muslim Bolaang Mongondow di sore terakhir bulan Syaban. Prosesi mandi massal dipimpin oleh seorang jiow yang akan menyiramkan air ke orang-orang. Hal ini sudah berlangsung sejak lama, dan lahirnya tradisi mandi puasa secara massal merupakan jawaban dari kebutuhan masyarakat muslim Bolaang Mongondow yang ingin melaksanakan mandi puasa Ramadan. Selain itu, pelaksanaan tradisi Monginbalu Konbulan juga sarat nilai, sehingga membuatnya urgen untuk dilestarikan sebagai kekhasan tradisi Islam Nusantara dalam masyarakat muslim Bolaang Mongondow.
\end{abstract}

Kata Kunci: Menyambut Ramadan, Mandi Bersama, Tradisi Bolaang Mongondow, Tradisi Islam Nusantara

\title{
PENDAHULUAN
}

Nusantara memiliki banyak kekayaan yang menarik untuk diteliti. Kekayaan tersebut tidak hanya pada sumber alamnya, tapi juga budaya dan tradisi keagamaannya. Banyaknya suku bangsa di Indonesia, tentu saja berdampak pada kemajemukan budaya yang dimiliki. ${ }^{1}$ Setiap suku punya budaya yang menghiasi kehidupan mereka. Ragam tradisi pun lahir menghiasi tanah Nusantara. Tradisi merupakan proses situasi kemasyarakatan yang di dalamnya terdapat unsur-unsur dari warisan kebudayaan dan dipindahkan dari generasi ke generasi. ${ }^{2}$ Sederhananya, tradisi merupakan ekspresi budaya suatu masyarakat yang terus terjaga dan terwariskan.

Islam masuk ke Nusantara tidak dalam ruang hampa, namun hadir di tengah masyarakat yang telah memiliki kebuda-

${ }^{1}$ Agus Iswanto, "Keraton Yogyakarta dan Praktik Literasi Budaya Keagamaan Melalui Media Digital," Jurnal Lektur Keagamaan, Volume 17, No. 2 (2019), 323.

${ }^{2}$ Amru Almu'tashim dan Jerry Hendrajaya, "Tradisi Selamatan Kematian Nyatus Nyewu: Implikasi Nilai Pluralisme Islam Jawa," Jurnal Lektur Keagamaan, Volume 17, No. 2 (2019), 432. 
yaan. Masuknya Islam ke Nusantara turut memberi pengaruh besar terhadap kebudayaan dan adat-istiadat masyarakat setempat. $^{3}$ Dalam sejarahnya, perkembangan Islam yang pesat mewujud dalam bentuk perjumpaan antar berbagai unsur kehidupan: pola budaya, tradisi, nilai, norma yang lama dengan yang baru, sehingga Islam cepat tersebar di masyarakat Nusantara. ${ }^{4}$ Para penyebar Islam di Nusantara tak serta merta melakukan perubahan sosial keagamaan secara cepat. Atau, menghilangkan nilainilai budaya lokal yang telah turun-temurun dengan nilai-nilai budaya Islam yang baru diperkenalkan. ${ }^{5}$ Sebaliknya, budaya menjadi salah satu media Islamisasi. Islam datang ke Indonesia melalui budaya dan peradaban yang luhur. ${ }^{6}$ Tak mengherankan kalau kemudian banyak budaya atau tradisi Islam lokal yang berkembang dalam masyarakat muslim di Nusantara, yang itu menghasilkan kekhasan Islam di Nusantara.

Islam Nusantara merupakan Islam khas, yang secara substansi sebagaimana yang ada di Arab (di mana Nabi Muhammad Saw. dan al-Qur' an bermula dari sana). Saat Islam menyebar di Nusantara, terjadi dialektika aktif antara Islam dengan budaya tradisi masyarakat. Dialektika tersebut membentuk Islam yang khas ala Nusantara yang disebut Islam Nusantara. ${ }^{7}$ Sangat banyak warisan-warisan Islam Nusantara, ada yang berupa arsitekstur masjid yang khas, seperti di Masjid Sultan Ayyub Sanggau yang dibangun dengan sentuhan arsitektur Hindu dan

${ }^{3}$ Donald Qomaldiansyah Tungkagi, "Varian Islam Nusantara: Jawa, Minangkabau Dan Gorontalo," Jurnal Lektur Keagamaan, Volume 15, No. 2 (2017), 275.

${ }^{4}$ Choirul Fuad Yusuf, "Kesultanan Nusantara dan Faham Keagamaan Moderat Di Indonesia," Jurnal Lektur Keagamaan, Volume 14, No. 2 (2016), 463.

${ }^{5}$ M. Kasim Abdurrahman, “Arsitektur Masjid Jami'Sultan Ayyub Sanggau," Jurnal Lektur Keagamaan, Volume 12, No. 1 (2014), 237.

${ }^{6}$ Amirul Ulum, Al-Jawi Al-Makki: Kiprah Ulama Nusantara Di Haramain, 2nd Ed. (Yogyakarta: Global Press, 2019), 22.

${ }^{7}$ Efa Ida Amaliyah, "Nilai-Nilai Kearifan dalam Tradisi Perang Obor Di Tegalsambi-Jepara Sebagai Karakteristik Islam Nusantara," Jurnal Lektur Keagamaan, Volume 16, No. 2 (2014), 398. 
Islam. ${ }^{8}$ Serta, juga Masjid Sunan Giri yang bergaya perpaduan budaya lokal tradisional Jawa dan Hindu. ${ }^{9}$ Dalam tradisi penulisan kitab-kitab keagamaan juga ditemukan kekhasan Islam Nusantara, di mana adanya penggunaan huruf Arab pegon, semisal Tafsir Faid ar-Rahman fi Tarjamah Kalam Malik adDyan karya Kiai Saleh Darat, yang ditulis di lingkungan pesantren Pesisir Jawa dengan menggunakan aksara pegon. ${ }^{10}$ Serta, masih banyak lagi berbagai macam kekhasan Islam Nusantara dari berbagai aspek keagamaan.

Salah satu tradisi Islam Nusantara dalam masyarakat muslim Bolaang Mongondow adalah Monginbalu Konbulan. ${ }^{11}$ Monginbalu Konbulan merupakan tradisi mandi puasa secara massal saat akan memasuki bulan Ramadan. Tradisi ini mirip dengan tradisi mandi safar dalam masyarakat Melayu. Hanya saja beda pada waktu pelaksanaan serta motif di baliknya. Kalau mandi safar dilaksanakan pada bulan Safar, sedangkan tradisi Monginbalu Konbulan dilaksanakan pada bulan Syaban, tepat sore hari terakhir saat akan masuk malam pertama bulan Ramadan.

Tradisi yang serupa Monginbalu Konbulan adalah tradisi mandi suci sambut Ramadan dalam masyarakat Desa Siwuluh, Kec. Bulukumba, Kab. Brebes, Jawa Tengah. Hanya saja dalam pelaksanaannya, tidak seperti di Siwuluh ada kepercayaan air kolam suci yang dianggap punya banyak khasiat. ${ }^{12}$ Dalam Monginbalu Konbulan masyarakat muslim Bolaang Mongondow, tidak dihiasi kepercayaan demikian, hanya ada niat untuk mandi menyucikan diri, karena akan berpuasa Ramadan.

\footnotetext{
${ }^{8}$ Abdurrahman, “Arsitektur Masjid...”, 254.

${ }^{9}$ Novita Siswayanti, “Akulturasi Budaya Pada Arsitektur Masjid Sunan Giri,” Jurnal Lektur Keagamaan, Volume 14, No. 2 (2016), 325.

${ }^{10}$ Siti Mariatul Kiptiyah, "Tradisi Penulisan Tafsir Al-Qur'an Bahasa Jawa,” Jurnal Lektur Keagamaan, Volume 15, No. 2 (2017), 423.

${ }^{11}$ Bolaang Mongondow yang penulis maksud adalah suku Bolaang Mongondow (atau suku Mongondow). Jadi, tak hanya terbatas pada wilayah Kabupaten Bolaang Mongondow, namun mencakup semua daerah Bolaang Mongondow lainnya atau sering disebut Bolaang Mongondow Raya (BMR).

${ }^{12}$ Redaksi, "Mandi Suci Sambut Ramadhan,” NU Online, 2008, https:// www.nu.or.id/post/read/13570/mandi-suci-sambut-ramadhan.
} 
Pelaksanaannya juga tidak terbatas hanya di kolam, namun bisa di sungai, sumber mata air, serta tempat yang memungkinkan dilaksanakannya mandi suci secara massal untuk menyiapkan diri menyambut Ramadan. Di Kelurahan Tabang, Kota Kotamobagu, memang terdapat kolam yang berasal dari sumber mata air, masyarakat setempat menamainya dengan Kotagatan. Namun, kolam ini tidak diyakini sebagai kolam suci, melainkan hanya kolam mata air biasa yang dimanfaatkan masyarakat setempat untuk mencuci maupun mengambil pasokan air bersih. Hal yang membuat Kotagatan memiliki nilai sejarah adalah sebab sudah ratusan tahun belum pernah kering.

Selain itu, ada juga beberapa tradisi mandi puasa Ramadan di daerah-daerah yang lain, namun memiliki perbedaan mendasar dalam hal pelaksanaan dengan Monginbalu Konbulan. Misalnya, Mandi Balimau Kasai di Riau yang dilaksanakan untuk menyambut puasa Ramadan. Seperti nama tradisinya bahwa air untuk mandi dalam tradisi ini dicampur lemon, sehingga dinamakan mandi lemon. ${ }^{13}$ Ada juga Ngeloop Saga Puasa, yaitu tradisi mandi dan merendam diri di laut untuk menyambut Ramadan dalam masyarakat muslim Lampung. ${ }^{14}$ Begitu juga tradisi Mandi Pangir, merupakan tradisi mandi puasa yang dilakukan oleh perempuan etnis Jawa di Pagarungan. ${ }^{15}$ Prosesi Monginbalu Konbulan berbeda dengan ketiga tradisi tersebut, di mana pelaksanaannya umumnya bukan dilakukan di laut, serta tidak menggunakan campuran bahan apa pun pada air yang dipakai untuk mandi, dan tradisi ini berlaku umum -tidak hanya bagi perempuan saja-.

${ }^{13}$ Razali Pebrianto, Heri Saputra, dan Nurhasanah Bakhtiar, "Kearifan Lokal Dalam Tradisi Mandi Balimau Kasai: Peran Pemangku Adat Untuk Menjaga Nilai-Nilai Islam Di Desa Alam Panjang Kec. Rumbio Jaya Kab. Kampar Prov. Riau," JUSPI (Jurnal Sejarah Peradaban Islam), Volume 3, No. 1 (2019), 18.

${ }^{14}$ Napsiah, "Ngeloop Haga Puasa: Praktik Sosial Budaya Menyambut Ramadan Untuk Penguatan Identitas Muslim," Society, Volume 8, No. 1 (2020), 46.

${ }^{15}$ Dewi Lismaria Malau, "Tradisi Mandi Pangir Pada Perempuan Etnis Jawa Dalam Menyambut Bulan Ramadahn Di Desa Pangarungan Kec. Torgamba Kota Pinang" (Universitas Negeri Medan, 2018), 2. 
Penjelasan ragam tradisi mandi massal di atas mengindikasikan bahwa terdapat kekhasan pada tradisi Monginbalu Konbulan dalam lokalitas masyarakat muslim Bolaang Mongondow, yang membedakannya dengan tradisitradisi mandi puasa di daerah yang lain di Nusantara. Meski belum ada kejelasan kapan tradisi Monginbalu Konbulan mulai muncul, namun yang jelas tradisi ini sudah ada sejak lama dalam masyarakat muslim Bolaang Mongondow.

Tradisi semacam ini oleh sebagian muslim tidak dapat diterima dan dipandang sebagai bidah yang sesat, sebab menurut mereka praktik ini tidak dicontohkan Nabi Muhammad Saw. Padahal, ada sebuah atsar dari Sahabat Abdullah bin Mas'ud ra, yang menjelaskan bahwa sesuatu yang dipandang baik oleh orang-orang mukmin (yang alim), maka perkara tersebut adalah baik. ${ }^{16}$ Hadirnya tradisi ini sebagai bagian kebutuhan pengamalan ajaran Islam dalam masyarakat muslim di Bolaang Mongondow Raya, karena itu hingga sekarang pelaksanaan Monginbalu Konbulan masih terus dilakukan dan dirasa penting oleh masyarakat, sebab sarat nilai dalam pelaksanaannya.

Kajian terkait topik tradisi mandi untuk menyambut bulan Ramadan di daerah atau suku yang lain telah banyak dilakukan. Beberapa di antaranya adalah Razali Pebrianto, Heri Saputra, dan Nurhasanah Bakhtiar ${ }^{17}$ mengkaji tradisi Balimau Kasai atau tradisi mandi lemon. Kajian mereka menekankan pada bagaimana peran dari para pemangku adat setempat dalam menjaga nilai-nilai Islam pada tradisi Balimau Kasai. Pemangku adat berperan dalam memberi pemahaman kepada masyarakat, dan dapat menghimbau masyarakat agar terhindar dari hal-hal berlebihan dan menyimpang dari maksud tradisi Balimau $\mathrm{Kasai}^{18}{ }^{8}$ sehingga dengan demikian nilai-nilai Islam dalam tradisi ini dapat terus terjaga.

Napsiah mengkaji tradisi Ngelop Haga Puasa dalam masyarakat muslim Lampung. Fokus kajiannya pada upaya menelusuri bagaimana tradisi ini mampu menguatkan identitas

\footnotetext{
${ }^{16}$ Ulum, Al-Jawi Al-Makki, 50.

${ }^{17}$ Pebrianto, Saputra, dan Bakhtiar, "Kearifan Lokal...", 17-24.

${ }^{18}$ Pebrianto, Saputra, dan Bakhtiar, "Kearifan Lokal...", 23.
} 
muslim bagi masyarakat Lampung Selatan. Salah satu yang ditemukannya adalah sebagai ekspresi dalam bentuk praktek budaya lokal tradisi ini mampu menguatkan identitas muslim warga setempat. ${ }^{19}$

Dewi Lismania Malau melakukan kajian terhadap tradisi Mandi Pangir. Kajian ini menelusuri alasan kenapa hanya perempuan yang melakukan tradisi Mandi Pangir, serta apa makna tradisi ini dan bahan rebusan air yang digunakan dalam tradisi ini. $^{20}$ Dalam kesimpulannya, salah satu alasan hanya perempuan yang melakukan Mandi Pangir adalah dianggap tabu jika mandi bersama laki-laki. Selain itu, tradisi ini memiliki makna sakral, terlebih tempat sumur yang digunakan untuk mandi juga sudah dianggap tua dan keramat, serta bahan-bahan yang dibutuhkan dalam Mandi Pangir adalah daun pandan, jeringan, daun nilam, daun serai, tanaman laos, dan daun jeruk purut. ${ }^{2}$

Tulisan ini mengkaji tradisi Monginbalu Konbulan pada masyarakat muslim Bolaang Mongondow dan mencoba menelusuri sejarah kemunculan tradisi Monginbalu Konbulan, serta nilai-nilai yang terkandung dalam pelaksanaan tradisi ini yang membuatnya menjadi penting bagi masyarakat muslim Bolaang Mongondow. Sebagai upaya mengarahkan pembahasan dalam tulisan ini, maka rumusan masalah yang menjadi fokus tulisan adalah; 1) Bagaimana praktik tradisi Monginbalu Konbulan dalam masyarakat muslim Bolaang Mongondow? 2) Bagaimana sejarah munculnya tradisi Monginbalu Konbulan? Serta, 3) Apa nilai-nilai yang terkandung dalam tradisi Monginbalu Konbulan?

Dalam upaya mengkaji sejarah tradisi Monginbalu Konbulan maka dibutuhkan pendekatan historis. Menurut ilmu sejarah segala peristiwa dapat dilacak dengan melihat kapan peristiwa terjadi, di mana, kenapa, serta siapa yang terlibat di

${ }^{19}$ Napsiah, "Ngeloop Haga Puasa...", 39.

${ }^{20}$ Malau, "Tradisi Mandi Pangir Pada Perempuan Etnis Jawa Dalam Menyambut Bulan Ramadahn Di Desa Pangarungan Kec. Torgamba Kota Pinang," i.

\footnotetext{
${ }^{21}$ Malau, 67-68.
} 
dalamnya. ${ }^{22}$ Pendekatan sejarah sangat dibutuhkan dalam memahami agama (termasuk dalam tulisan tradisi keagamaan), sebab agama sendiri turun dalam situasi yang konkret bahkan berkaitan dengan kondisi sosial masyarakat. ${ }^{23}$

Selain menggunakan pendekatan sejarah, artikel ini juga menggunakan pendekatan antropologi untuk memahami nilai dan proses lahirnya tradisi Monginbalu Konbulan. Dalam hal ini, penulis menggunakan fungsionalisme Molinowski. Meski termasuk teori klasik dalam antropologi, namun masih relevan digunakan dalam kajian masyarakat dan kebudayaan. ${ }^{24}$ Asumsi dasar dari fungsionalisme Molinowski adalah kebudayaan maupun tradisi lahir atas respon kebutuhan manusia, dengan kata lain tradisi merupakan perpanjangan tangan dari kebutuhan manusia. ${ }^{25}$ Selain itu, memahami konsep teori difusi budaya juga penting dalam upaya membaca munculnya penyebaran tradisi Monginbalu Konbulan di desa-desa Bolaang Mongondow Raya. Difusi Budaya memandang kalau penjalaran suatu budaya terjadi karena manusia mengalami migrasi dari satu tempat ke tempat lain. Manusia yang berpindah selalu membawa budayanya, sehingga ketika bertemu dengan manusia lain, maka terjadilah pertemuan budaya. $^{26}$

Agar lebih bisa memahami secara utuh adanya tradisi Monginbalu Konbulan, juga digunakan pendekatan sosiologis. Pendekatan sosiologis dalam penggambaran peristiwa masa lalu, akan mengungkap segi-segi sosial dari peristiwa yang dikaji. ${ }^{27}$ Solidaritas Durkheim memandang kalau masyarakat tak diikat oleh kesamaan antara orang-orang yang melakukan pekerjaan

${ }^{22}$ Mokh. Fatkhur Rokhzi, "Pendekatan Sejarah Dalam Studi Islam," Jurnal Modeling, Volume 3, No. 1 (2015), 92.

${ }^{23}$ Rokhzi, 93.

${ }^{24}$ Moh. Soehadha, Fakta Dan Tanda Agama: Suatu Tinjauan SosioAntropologi, (Yogyakarta: Diandra Pustaka Indonesia, 2014), 45.

${ }^{25}$ Soehadha, 51.

${ }^{26}$ Maharsi, "Kuliah Islam dan Budaya Lokal," Di Kelas Islam Nusantara, Interdisciplinary Islamic Studies, Pascasarjana UIN Sunan Kalijaga Yogyakarta, 11 Desember 2020.

${ }^{27}$ Dudung Abdurrahman, Metodologi Penelitian Sejarah Islam, (Yogyakarta: Ombak, 2011), 11. 
yang sama, namun pembagian kerjalah yang mengikat masyarakat dengan memaksa mereka agar tergantung satu sama lain. Solidaritas menunjuk pada suatu keadaan hubungan antara individu atau kelompok yang didasarkan pada perasaan moral dan kepercayaan yang dianut bersama serta diperkuat oleh pengalaman emosional bersama. ${ }^{28}$ Meski teori ini lebih condong pada memahami masyarakat modern, namun penulis memandang kalau dengan Solidaritas Durkheim akan membantu dalam upaya membaca sejarah serta nilai dari tradisi Monginbalu Konbulan yang masih terus dilakukan hingga sekarang.

Metode tulisan yang digunakan adalah metode historis. Melalui metode ini digali sejarah serta terungkap nilai-nilai dari tradisi Monginbalu Konbulan dalam masyarakat muslim Bolaang Mongondow. Adapun langkah atau tahapan yang dilakukan adalah: 1) Heuristik, merupakan tahapan pengumpulan data sejarah. ${ }^{29}$ Pengumpulan sumber dilakukan lewat wawancara pada para jiow (imam) yang dipandang otentik dalam menerangkan tradisi Monginbalu Konbulan. Selain itu, untuk memperkaya data, penulis juga banyak berdiskusi dengan sesama orang Mongondow dan orang-orang yang pernah melakukan tradisi ini. 2) Verifikasi merupakan tahapan dalam mencari keabsahan atas sumber-sumber yang telah terkumpul. ${ }^{30}$ Perlu diingat kalau sumber lisan tidak serta merta kalah otentik dibanding sumber tulisan. Bahkan, bisa jadi, dalam kondisi tertentu, sumber lisan lebih otentik dibanding sumber tulisan. Semisal, di mana, sumber lisan yang sudah ahli atau pelaku tradisi dapat memberikan informasinya dengan baik. ${ }^{31}$ 3) Interpretasi, adalah tahap dalam menafsirkan serta menyimpulkan data yang diperoleh dan diyakini kebenarannya dengan berlandaskan kerangka teori. ${ }^{32}$ Pada

${ }^{28}$ Diah Retno Dwi Hastuti et al., "Emile Durkheim (1858-1917)," in Ringkasan Kumpulan Mazhab Teori Sosial (Biografi, Sejarah, Teori, Dan Kritikan), ed. Zaiful, 1st ed. (Pustaka Taman Ilmu, 2018), 34. 2007), 95 .

${ }^{29}$ Helius Sjamsuddin, Metodologi Sejarah, (Yogyakarta: Ombak,

${ }^{30}$ Abdurrahman, Metodologi Penelitian Sejarah Islam, 105.

${ }^{31}$ Abdurrahman, 110.

${ }^{32}$ Abdurrahman, 111. 
tahap ini data-data terkait tradisi Monginbalu Konbulan disusun menjadi satu kesatuan kesejara-han yang jelas. 4) Historiografi atau penulisan sejarah merupa-kan tahap terakhir dari sebuah penelitian sejarah. ${ }^{33}$ Tahap ini merupakan penyajian atas kajian yang dibahas, yaitu tradisi Monginbalu Konbulan dalam masyarakat muslim Bolaang Mongondow.

\section{HASIL DAN PEMBAHASAN}

\section{Islam di Bolaang Mongondow}

Bolaang Mongondow dahulu merupakan wilayah kerajaan yang terdiri dari beberapa bagian kerajaan: Kerajaan Bolaang Mongondow sebagai pusatnya dan menjadi penamaan dari serikat kerajaan ini, Kerajaan Kaidipang dan Kerajaan Bolangitang yang kemudian menjadi satu sebagai Kerajaan Kaidipang Besar, Kerajaan Bintauna, serta Kerajaan Bolaang Uki. Sekarang, wilayah ini merupakan daerah di Prov. Sulawesi Utara yang dikenal sebagai Bolaang Mongondow Raya, yang terdiri dari Kab. Bolaang Mongondow, Kab. Bolaang Mongondow Selatan, Kota Kotamobagu, Kab. Bolaang Mongondow Timur, dan Kab. Bolaang Mongondow Utara. Masyarakat di daerah ini mayoritas adalah muslim. Hal ini menjadikan Bolaang Mongondow sebagai salah satu daerah di Nusantara yang memiliki banyak tradisi Islam, misalnya Mintahang, Monuntul, dan Monginbalu Konbulan (tradisi yang akan dibahas dalam artikel ini).

Masifnya penyebaran Islam di Bolaang Mongondow dimulai pada awal abad $19 \mathrm{M}$. Sebelum Islam masuk di daerah ini, raja berserta keluarga dan rakyat memeluk agama Kristen Katolik. Selain itu, pengaruh praktek agama tradisional masih sangat kuat. Kepercayaan tradisional Bolaang Mongondow adalah shamanisme berupa ritual ancestor worship (penyembahan leluhur). ${ }^{34}$ Misalnya, momolapag yang merupa-

${ }^{33}$ Abdurrahman, 113.

${ }^{34}$ Moh. Rivaldi Abdul, "Tradisi Mintahang (Doa Arwah) Dan Kepercayaan Tradisional Bolaang Mongondow," Harakah.id, 2021, https:// harakah.id/tradisi-mintahang-doa-arwah-dan-kepercayaan-tradisionalbolaang-mongondow/. 
kan upacara penyembahan leluhur dengan menghidangkan sesajen, monayok yang merupakan ritus pemanggilan leluhur untuk mengobati orang yang sakit, dan lainnya. ${ }^{35}$ Ritual-ritual itu sangat mengakar di Bolaang Mongondow sebelum Islam diterima menjadi agama masyarakat daerah ini.

Selain itu, meski kuat memegang kepercayaan tradisional, masyarakat Bolaang Mongondow sebelum menerima Islam, mereka juga memeluk agama Katolik. Namun, demikian sebagaimana dijelaskan Seven Kosel bahwa saat itu: “...there was no fuctioning Christian congregation...." "36 Artinya: tidak ada pemfungsian jamaat Kristiani. Dan juga: “...the interior population is heathen." 37 Artinya, masyarakat pedalaman (yang bukan di pesisir) belum memeluk agama. Saat itu, ritual-ritual agama tradisional Bolaang Mongondow masih sangat melekat di masyarakat.

Islam mulai tersebar secara masif di Bolaang Mongondow mulai pada abad 19 M. Ini ditandai dengan meningkatnya jumlah pedagang Muslim Arab dan Bugis yang datang, bahkan sampai ada yang menetap dan kawin dengan masyarakat setempat. Selain itu, berbagai jaringan ulama juga semakin masif dalam menjalankan dakwah Islam di Bolaang Mongondow. ${ }^{38}$ Di Lipung Simboy Tagadan (sekarang Kelurahan Motoboi Kecil), diketahui merupakan daerah yang awal-awal memiliki komunitas muslim. Wilayah ini menjadi daerah garapan dakwah dari jaringan ulama Gorontalo, yang disebut Tim 9, sebab jumlah mereka ada 9 orang dengan kepalanya adalah Imam Tueko. ${ }^{39}$

Ketika Tim 9 melakukan pagelaran seni keislaman, Raja Jakobus Manuel Manoppo (1833-1858) menghadiri pagelaran

${ }^{35}$ Hamri Manoppo et al., Dinamika Islamisasi Di Bolaang Mongondow Raya Sulawesi Utara, Abad Ke-17-20, (Jakarta: Litbangdiklat Press, 2020), 62.

${ }^{36}$ Seven Kosel, "The History of Islam in Bolaang Mongondow, North Sulawesi," Indonesia and the Malay World, Volume 38, No. 110 (2010): 51.

${ }^{37}$ Kosel, 51.

${ }^{38}$ Moh. Rivaldi Abdul, "Awal Mula Kehadiran Islam Di Bolaang Mongondow," Alif.id, 2021, https://alif.id/read/moh-rivaldi-abdul/awal-mulakehadiran-islam-di-bolaang-mongondow-b237006p/.

${ }^{39}$ Litbang Amabon, Mengenal Bolaang Mongondow: Sejarah, Adat, Dan Budaya, (Kotamobagu: Sembilan Bintang, 2018), 42. 
itu. Waktu itu, beliau terpikat dengan anaknya Imam Tueko yang bernama Kilingo. Kilingo merupakan muslimah yang fasih membaca al-Qur'an dan merdu suaranya saat melantunkan qasidah (lagu religi ala Gorontalo). Dirinya adalah salah satu dari Tim 9, dan merupakan anaknya Imam Tueko. Raja jatuh hati padanya ketika melihat dirinya dalam pagelaran yang diselenggarakan oleh Tim $9 .^{40}$

Sebenarnya, kehadiran raja memang sangat diharapkan dalam pertunjukan tersebut. Sebab, salah satu tujuan dari pagelaran itu adalah untuk mendekati dan mengenalkan Islam kepada raja dan masyarakat Bolaang Mongondow. ${ }^{41}$ Sebelumnya, jaringan ulama ini telah melakukan penelusuran dan menemukan fakta bahwa, jika raja berhasil di-Islamkan maka proses Islamisasi masyarakat Bolaang Mongondow akan semakin masif. ${ }^{42}$ Sebab, orang Mongondow punya prinsip: dumodui kon agama in datu (ikut agama datu/raja). ${ }^{43}$ Sehingga, salah satu target yang harus mereka Islamkan adalah Raja Jakobus Manuel Manoppo.

Sebagaimana telah dijelaskan sebelumnya, bahwa raja jatuh hati pada Boki (Putri) Kilingo. Sehingga, raja pun melamar Kilingo, dan itu tentu disambut baik oleh ayahnya, Imam Tueko. Sebelum raja menikahi Kilingo, Imam Tueko memberi syarat bahwa raja harus masuk Islam terlebih dahulu sebelum menikahi putrinya. Hal itu disanggupi oleh raja hingga dirinya pun memeluk Islam dan menjadi seorang mualaf.

Kapan waktu Raja Jakobus memeluk Islam, sepanjang penelusuran literatur, terdapat beberapa sumber yang menyebutkan awal mula raja memeluk Islam dengan tahun yang berbeda. Jeremy Stickings, dalam catatan etnografinya,

${ }^{40}$ Amabon, 43.

${ }^{41}$ Moh. Rivaldi Abdul, "Sejarah Islam Di Bolaang Mongondow: Sultan Jakobus Manuel Manoppo Dan Keislamannya," Iqra.id, 2021, https:// iqra.id/sejarah-islam-di-bolaang-mongondow-sultan-jakobus-manuelmanoppo-dan-keislamannya-234423/.

${ }^{42}$ Manoppo et al., Dinamika Islamisasi Di Bolaang Mongondow Raya Sulawesi Utara, 94.

${ }^{43}$ Manoppo et al., 6-7.

${ }^{44}$ Amabon, Mengenal Bolaang Mongondow, 43. 
menjelaskan bahwa: "...he conversion of the raja in 1844.",45 Artinya: perubahan agama raja terjadi pada 1844. Dalam catatan yang lebih tua dari Wilken dan Schwarz: Het Heidendom en de Islam in Bolaang Mongondou (1867), sebagaimana yang dikutip Seven Kosel dalam artikelnya bahwa: "...the conversion of the raja to Islam on his return from Manado...."46 Artinya: raja masuk Islam sekembalinya dari Manado. Dan, diketahui bahwa kepergian Raja Jakobus Manuel Manoppo menghadap Residen Belanda di Manado untuk menyatakan diri masuk Islam berserta rakyatnya adalah pada $1848,{ }^{47}$ sementara dalam tulisannya yang lain Seven Kosel mengatakan kepergian raja tersebut adalah pada 1844. ${ }^{48}$ Dalam disertasinya A. C. Lopez dijelaskan kalau kepergian Raja Jakobus Manuel Manoppo menghadap Residen Belanda, A. J. van Olpen, di Manado untuk menyatakan diri masuk Islam adalah pada $1848 .{ }^{49}$ Tahun ini diperkuat dengan penjelasan dalam tulisannya W. Dunnebier, seorang misionaris Belanda yang pernah bertugas di Bolaang Mongondow pada abad $20 \mathrm{M}^{50}$

Meski ada perbedaan waktu mengenai masuk Islamnya Raja Jakobus Manuel Manoppo, namun yang pasti semua sepakat bahwa raja telah memeluk Islam. Dan saat itu, Raja Jakobus Manuel Manoppo juga mengajak keluarga serta rakyatnya untuk ikut menerima Islam sebagai agama mereka. Residen Belanda di Manado juga tidak keberatan dengan perubahan

${ }^{45}$ Jeremy Stickings, "Bolaang-Mongondow: Some Notes on History and Adat," Indonesia Circle. School of Oriental and African Studies. Newsletter, Volume 7, No. 18 (1979), 22.

${ }^{46}$ Kosel, "The History of Islam...", 51.

${ }^{47}$ Kosel, 51.

${ }^{48}$ Seven Kosel, "Chistian Mission in an Islamic Environment: Religious Conversion in North Sulawesi in the Light of a Case-Study from Bolaang Mongondow," Paideuma, 51 (2005), 45.

${ }^{49}$ Ariel C. Lopez, "Conversion and Colonialism: Islam and Christianity in North Sulawesi, c. 1700-1900” (Leiden University, 2018), 115.

${ }^{50}$ William Dunnebier, "Over de Vorsten van Bolaang Mongondow," Bijdragen Tot de Taal-, Land-En Volkenkunde, Volume 105, No. 1 (1949), 255. 
agama raja serta rakyatnya. Bagi Belanda yang terpenting adalah raja tetap loyal kepada pemerintahan mereka. ${ }^{51}$

Menurut Seven Kosel sebagaimana dia mengutip catatan dari S. Ulfers (1859), seorang misionaris yang diutus ke Sulawesi Utara, bahwa meski saat itu raja berstatus sebagai penganut Katolik, namun sebenarnya tidak tahu apa-apa tentang Kristen, parahnya lagi permohonannya agar Residen Belanda menghadirkan guru agama Kristen ke Bolaang Mongondow tidak mendapat respon baik. Sehingga, saat ada tawaran untuk masuk Islam (dari Tim 9), maka: "...he found a way to get rid of this [Christian] label." 52 Artinya: dia menemukan jalan untuk menghilangkan status Kristen.

Raja Jakobus Manuel Manoppo pun masuk Islam dan diikuti oleh keluarga serta rakyatnya. Residen Belanda di Manado kemudian memberinya gelar sebagai sultan. ${ }^{53}$ Itulah kenapa meski Bolaang Mongondow bukan kesultanan, namun nisan di makam beliau bertuliskan gelar sultan: Sultan Jakobus Manuel Manoppo.

W. Dunnebier menjelaskan bahwa sejak Raja Jakobus Manuel Manoppo memeluk Islam, Muhammadisasi (Islamisasi) semakin masif di Bolaang Mongondow. ${ }^{54}$ Proses ini berlangsung pada abad ke-19 M, sehingga secara umum penyebaran Islam bisa dikatakan mulai masif di Bolaang Mongondow adalah sejak abad 19 M. Namun, sebenarnya jauh sebelum Raja Jakobus Manuel Manoppo menerima Islam, Bolaang Mongondow sudah mulai bersentuhan dengan Islam.

Sultan Hairun yang memerintah Tarnate di abad ke-16 M pernah mengirimkan utusan untuk menyebarkan Islam di daerah ini. Bahkan, kabarnya Punu' Busisi (punu' setara makna dengan raja) yang memerintah Bolaang Mongondow sekitar 1510-1540 telah di-Islamkan oleh seorang utusan dari Tidore bernama Kaicil Guzarate. Namun, beliau kemudian memilih untuk keluar

\footnotetext{
${ }^{51}$ Kosel, "Chistian Mission...", 45.

${ }^{52}$ Kosel, "The History of Islam...", 54.

${ }^{53}$ Amabon, Mengenal Bolaang Mongondow, 44.

${ }^{54}$ Dunnebier, "Over de Vorsten...", 255.
} 
dari Islam dan masuk Kristen. ${ }^{55}$ Selain itu, beberapa sumber menyebutkan bahwa Raja Loloda Mokoagow (1653-1693) yang menjadi Raja Bolaang Mongondow pada abad $17 \mathrm{M}$ juga telah memeluk Islam berkat kedekatannya dengan Sultan Tarnate. ${ }^{56}$ Jadi, bisa dikatakan kalau raja pertama yang beragama Islam di Bolaang Mongondow bukanlah Raja Jakobus Manuel Manoppo, melainkan Raja Loloda Mokoagow. Terkait Punu' Busisi sekalipun benar beliau telah diislamkan, namun juga dijelaskan bahwa kemudian memilih untuk keluar dari Islam. Sehingga, Raja Loloda Mokoagow yang lebih tepat disebut sebagai raja muslim pertama di Bolaang Mongondow. Terlepas dari beberapa sumber yang menyebutkan bahwa keislamannya hanya formalitas diplomasi antara Bolaang dan Ternate, dan juga beliau tidak mengembangkan dakwah di lingkungan istana dan masyarakat, sehingga Islam tidak berkembang bahkan setelah periode Kristenisasi menjadi masif di daerah ini. ${ }^{57}$

Hal yang perlu diingat juga bahwa sebelum masifnya Islamisasi di masa Raja Jakobus, berbagai upaya penyebaran Islam sudah berlangsung di daerah ini. Sehingga, telah ada beberapa kelompok masyarakat muslim. Bahkan, kalau mencermati dari data Pietermaat yang dikutip Seven Kosel: “...for some headmen who follow the teaching of Mohammed...." sudah ada beberapa kepala kampung yang memeluk ajaran Muhammad. Selain itu, di kawasan Bolaang Mongondow Utara sebagaimana penjelasan Tungkagi bahwa Raja Kaidipang yang pertama masuk Islam adalah Raja Waladin Korompot (17791817), serta di Bintauna raja muslim pertama adalah Raja Patilima (Datunsolang) yang penobatannya dilakukan di Ternate pada $1783 .^{59}$

${ }^{55}$ Manoppo et al., Dinamika Islamisasi Di Bolaang Mongondow Raya Sulawesi Utara, 82.

${ }^{56}$ Amabon, Mengenal Bolaang Mongondow, 41.

${ }^{57}$ Amabon, 41-42.

${ }^{58}$ Kosel, "The History of Islam...", 51.

${ }^{59}$ Donald Qomaldiansyah Tungkagi, "Islam di Bolaang Mongondow Utara, Sulawesi Utara: Dinamika Islamisasi Di Kerajaan Kaidipang Besar 
Bisa disimpulkan kalau sebelum abad ke-19 M, di Bolaang Mongondow Raya sudah ada tempat yang lebih dulu menjadi wilayah dakwah, dan juga telah ada yang memeluk Islam. Kemudian, gerakan Islamisasi di Bolaang Mongondow semakin memuncak pada awal abad ke-19 M. Jadi, dapat dipahami bahwa persentuhan Islam dengan Bolaang Mongondow mulai terjadi sejak abad ke-16-17 M. Namun, penyebaran Islam mulai menemukan momen kemasifannya adalah di abad ke-19 M, dan setelah itu Islam terus mengalami perkembangan yang sangat signifikan di Bolaang Mongondow. Sehingga, hasilnya masyarakat Bolaang Mongondow menjadi masyarakat muslim yang punya banyak tradisi keislaman, salah satunya adalah tradisi Mongonbalu Konbulan dalam menyambut puasa Ramadan.

\section{Praktik Tradisi Monginbalu Konbulan (Mandi Puasa Secara Massal)}

Salah satu tradisi masyarakat muslim Bolaang Mongondow dalam menyambut puasa Ramadan adalah Monginbalu Konbulan. Tradisi ini sudah sangat lama dilakukan. Tidak semua desa di Bolaang Mongondow Raya yang melakukannya, ada sebagian desa yang tak melakukan tradisi ini, baik karena lingkungan desa tersebut tidak memiliki lokasi yang kondusif untuk mandi massal, serta alasan lainnya. Ada juga yang dulu melakukannya, namun sebab beberapa alasan, sekarang sudah tidak lagi. Misalnya, di Desa Bilalang 3 tidak melaksanakan tradisi ini. ${ }^{60} \mathrm{Di}$ Desa Tuduaog (masih bagian dari desa-desa Bilalang), dulu melaksanakannya, namun sekarang sudah tidak lagi, sebab salah satu alasannya jauh dari sungai besar yang kondusif untuk pelaksanaan mandi massal. ${ }^{61}$ Selain itu, desa-desa di pesisir utara Bolaang Mongondow (Kab. Bolaang Mongondow Utara), terkhusus wilayah Buroko, Bolangitang, dan Kaidipang, tak melak-

Dan Bintauna Abad Ke-7-19 M," Jurnal Lektur Keagamaan, Volume 17, No. 2 (2019), 495-496.

${ }^{60}$ Diskusi Dengan Ara, Warga Desa Bilalang 3, Pada 20 Desember $2020 \mathrm{M}$.

${ }^{61}$ Diskusi Dengan Gunawan, Warga Desa Tuduaog, Pada 29 Desember 2020 M, Di Kota Gorontalo. 
sanakan tradisi ini. ${ }^{62}$ Sebagian desa-desa di wilayah pesisir selatan (Kab. Bolaang Mongondow Selatan) khususnya desadesa yang penduduknya suku Gorontalo dan Bolango, juga tak melaksanakannya. Umumnya, desa-desa di Bolaang Mongondow Raya yang ditempati masyarakat suku Mongondow melaksanakan tradisi ini, meski ada beberapa yang tidak, serta ada yang dulu melaksanakannya, tapi sekarang sudah tidak. Beberapa desa di Bolaang Mongondow Raya yang masih melaksanakan tradisi Monginbalu Konbulan antara lain, Tabang, Bangomolunow, Pinolosian, Tolotoyon, Nunuk, Kombot, Solog, Moyag, dan masih banyak lagi.

Kata Monginbalu Konbulan merupakan bahasa Mongondow yang secara sederhana berarti menjemput atau menyambut datangnya bulan, bulan yang dimaksud adalah Ramadan. Masyarakat muslim Bolaang Mongondow saat sudah mau masuk bulan Ramadan, menjemput atau mengawalinya dengan tradisi mandi suci, sebab besok sudah akan melakukan puasa Ramadan selama sebulan, maka jasmani harus bersih terlebih dahulu dengan cara mandi puasa Ramadan. Tradisi ini juga disebut dengan Mandi Bulan (bulan yang dimaksud adalah bulan Ramadan).

Sekilas, tradisi Monginbalu Konbulan dalam masyarakat muslim Bolaang Mongondow hampir sama dengan tradisi Mandi Safar. Bahkan ada yang sampai mengira kalau Monginbalu Konbulan itu sendiri merupakan tradisi Mandi Safar, namun dilakukan pada bulan Syaban tepatnya sehari sebelum puasa Ramadan. Pandangan ini muncul karena Monginbalu Konbulan juga merupakan tradisi mandi massal sama halnya Mandi Safar yang juga termasuk tradisi mandi massal. Tapi, sebenarnya, Monginbalu Konbulan merupakan tradisi yang berbeda dengan Mandi Safar.

${ }^{62}$ Hasil Diskusi Dengan Beberapa Teman Dari Bolangitang Dan 
Mandi Safar merupakan tradisi muslim Melayu, yaitu tradisi mandi massal di bulan Safar untuk tolak bala. ${ }^{63}$ Ada tiga hal utama dalam kegiatan Mandi Safar, yaitu menulis atau menghafal 7 ayat Al-Qur'an yang diawali dengan kata Salamun, berniat untuk mandi karena Allah Swt. dan mandi itu sendiri. ${ }^{64}$ Mandi Safar sudah menjadi ritual yang dilaksanakan pada hari rabu terakhir di bulan Safar. Prosesi Mandi Safar dimulai dengan penulisan 7 ayat al-Qur'an yang diawali dengan kata Salamun, kemudian tulisan itu dimasukkan ke air yang akan dipakai mandi massal. ${ }^{65}$ Berbeda dengan tradisi Monginbalu Konbulan, di mana pelaksanaannya adalah pada hari terakhir di bulan Syaban, sudah mau masuk Ramadan. Sebagaimana penjelasan Bapak Djamin, Jiow $^{66}$ yang tinggal di Kelurahan Tabang:

"Monginbalu Konbulan itu macam sebentar malam sudah akan mulai Tarawih (maksudnya Tarawih pertama), sorenya (masyarakat) dikumpul di air yang besar, air yang mengalir, untuk dimandikan di situ." 67

Selain itu, pelaksanaannya tak dilakukan dengan membaca 7 ayat keselamatan, serta tak dimaksudkan untuk tolak bala. Tradisi Monginbalu Konbulan dilakukan semata adalah untuk mandi puasa Ramadan, tanpa ada unsur kepercayaan lain. Serta, pelaksanaannya hanya dengan membaca niat mandi puasa Ramadan. Jelas Bapak Nidin, Jiow Desa Bangomolunow:

"Cara pelaksanaan, kalau di sini, kita membaca doa (niat mandi puasa Ramadan) di air lalu disiramkan ke mereka (yang akan mandi). Doa (atau niatnya), 'Nawaitu gusla min syahri Ramadana kullihi' atau 'Nawaitu gusla min syahri shauma Ramadana kullihi.' Kalau ni sendiri, kalau na banyak orang.

${ }^{63}$ Muhammad Ahsubli, "Ritual Budaya Mandi Safar Di Desa Tanjung Punak Pulau Rupat Kabupaten Bengkalis Provinsi Riau," Jurnal Aqlam, Volume 3, No. 1 (2018), 88.

${ }^{64}$ Ahsubli, "Ritual Budaya Mandi Safar...", 92.

${ }^{65}$ Ahsubli, "Ritual Budaya Mandi Safar...", 90.

${ }^{66}$ Sebutan untuk tokoh agama di Bolaang Mongondow Raya. Jiow sama halnya dengan pegawai syara, takmir masjid, kiai kampung atau imam kampung.

${ }^{67}$ Wawancara Dengan Jiow Desa Tabang, Djamin Mokodompit, Pada 20 Desember 2020 M, Tempat Kediamannya Di Tabang. 
Kalau kita memandikan banyak orang maka pakai $n a$, kalau cuma satu orang yang datang (mandi bulan) berarti Ramadani kullihi." 68

Ada perbedaan bacaan dalam memandikan puasa Ramadan dengan yang biasa dibaca oleh Bapak Djamin, Jiow dari Kelurahan Tabang, di mana dia biasanya membaca doa: "Allahumma ahilahum bil amni wasehati wasalamati waberkah rabbi wa rabbuka Allah."69 Tambahan, bahwa dalam pandangan Bapak Djamin, Jiow Kelurahan Tabang, kalau Monginbalu Konbulan termasuk bagian dari memuliakan Tuhan yang menciptakan alam ini-termasuk bulan dan manusia. ${ }^{70}$

Dari sini bisa dipahami kalau tradisi Monginbalu Konbulan bukanlah tradisi Mandi Safar, melainkan tradisi mandi puasa Ramadan yang biasa dilakukan oleh masyarakat muslim Bolaang Mongondow. Sebab, meski sama-sama tradisi mandi massal, namun keduanya memiliki perbedaan mencolok baik dari tata cara serta motif pelaksanaannya.

Tradisi yang serupa ini adalah tradisi mandi suci sambut Ramadan dalam masyarakat Desa Siwuluh, Kec. Bulukumba, Kab. Brebes, Jawa Tengah. Hanya saja dalam pelaksanaannya, tak seperti di Siwuluh yang dihiasi kepercayaan air kolam suci yang dianggap punya banyak khasiat. ${ }^{71}$ Dalam Monginbalu Konbulan masyarakat Bolaang Mongondow, tak ada kepercayaan yang demikian, selain niat untuk mandi puasa Ramadan, serta pelaksanaannya tak hanya di kolam, namun di sungai, sumber mata air, serta tempat yang memungkinkan dilaksanakannya mandi suci menyambut Ramadan secara bersama-sama. Semisal, di Desa Bangomolunow yang pelaksanaan Mandi Bulannya para jiow memimpin pelaksanaan mandi massal di satu

\footnotetext{
${ }^{68}$ Wawancara Dengan Jiow Desa Bangomolunow, Nidin Tolodo, Pada 20 Desember 2020 M, Tempat Di Masjid Desa Bangomolunow.

${ }^{69}$ Wawancara Dengan Jiow Desa Tabang, Djamin Mokodompit, Pada 20 Desember 2020 M, Tempat Kediamannya Di Tabang.

${ }^{70}$ Wawancara Dengan Jiow Desa Tabang, Djamin Mokodompit, Pada 20 Desember 2020 M, Tempat Kediamannya Di Tabang.

${ }^{71}$ Redaksi, "Mandi Suci Sambut Ramadhan."
} 
sungai dengan tiga lokasi yang berbeda. Jadi, masyarakat bebas memilih di lokasi mana mereka akan melaksankan tradisi ini. ${ }^{72}$

Di Kelurahan Tabang, terdapat kolam (kolam ini membentuk aliran air kecil) yang berasal dari sumber mata air, masyarakat setempat menyebutnya dengan Kotagatan. Namun, kolam ini tak diyakini sebagai kolam suci yang memberi banyak khasiat layaknya di Siwuluh, melainkan hanya kolam mata air biasa yang memiliki nilai sejarah sebab sudah ratusan tahun belum pernah kering. Sebagaimana penjelasan Bapak Djamin:

"Di sana (tempat pelaksanaan Monginbalu Konbulan), namanya Dakotagatan, di situ air keluar dari dalam tanah, dari batu. Tapi (meski hanya sumber mata air), airnya besar, dipakaikan pancuran.... Kalau kepercayaan khusus tidak ada. Cuma masyarakat menganggap itu (air di Kotagatan) bersih sekali, karena dari (mata air langsung). Jadi, dulu belum ada PAM, belum ada Aqua ini, kebanyakan orang ambil air dari sana, ada yang mengambil air langsung diminum, ada yang masih dipanaskan. Tergantung dari maunya orang yang mengambil. Tapi, biar langsung diminum di situ, tidak apa-apa kan memang langsung dari dalam tanah. Tidak lewat di mana-mana. Kalau dia masih lewat di salah satu (aliran air) masih ada kecurigaan mungkin, jangan-jangan, sudah kena apa. Tapi, itu memang langsung keluar kemari (dari sumber mata air langsung).,73

Kotagatan merupakan sumber mata air tua yang sudah ratusan tahun belum pernah kering, sehingga memiliki nilai sejarah di Kelurahan Tabang, Kota Kotamobagu. Tidak ada yang tahu pasti kapan kolam Kotagatan mulai terbentuk, namun dalam pemahaman Bapak Djamin sendiri bahwa itu sudah ada sejak zaman Paloko-Kinalang di Bolaang Mongondow. ${ }^{74}$

Namun tidak ada yang tahu pasti kapan tepatnya mata air itu mulai ada di Kelurahan Tabang, bahkan bisa jadi sebelum desa itu sendiri ada. Kalau mencermati penjelasan Bapak Djamin

\footnotetext{
${ }^{72}$ Wawancara Dengan Jiow Desa Bangomolunow, Nidin Tolodo, Pada 20 Desember 2020 M, Tempat Di Masjid Desa Bangomolunow.

${ }^{73}$ Wawancara Dengan Jiow Desa Tabang, Djamin Mokodompit, Pada 20 Desember 2020 M, Tempat Kediamannya Di Tabang.

${ }^{74}$ Wawancara Dengan Jiow Desa Tabang, Djamin Mokodompit, Pada 20 Desember 2020 M, Tempat Kediamannya Di Tabang.
} 
yang memberi dugaan sejak masih zaman Paloko-Kinalang. Di mana, Paloko-Kinalang adalah janji setia antara rakyat dan penguasa Bolaang Mongondow di zaman Punu' Tadohe ${ }^{75}$-Punu' setara makna dengan raja.

Selain itu, ada juga yang mengatakan kalau Kotagatan sudah ada sejak zaman Raja Loloda Mokoagow. ${ }^{76}$ Pada 1653 M, Kerajaan Bolaang Mongondow pertama kali bersentuhan dengan Islam, di mana Raja Loloda Mokoagow, yang adalah raja saat itu masuk Islam. ${ }^{77}$ Namun, tak serta merta ini bisa disangkut pautkan dengan lahirnya tradisi Monginbalu Konbulan, meng-ingat di zaman Raja Loloda yang memeluk Islam hanya beliau, sementara keluarga raja serta masyarakat Bolaang Mongondow waktu itu belum memeluk Islam. ${ }^{78}$

Sebagaimana penjelasan Bapak Djamin, kalau ia belum bisa memberi prediksi yang benar-benar tepat. Namun, jelasnya, Kotagatan sudah sangat tua. Tersebut dalam cerita, kalau di seluruh Kotamobagu dahulu pernah dilanda kekeringan, dan hanya air Kotagatan-lah yang tak kering waktu itu. ${ }^{79}$ Maka Kotagatan menjadi sumber air penting di kala itu. Tak pernah keringnya kolam air ini meski sudah ratusan tahun, membuat Kotagatan di Tabang menjadi kolam yang memiliki nilai sejarah.

Dalam tradisi Monginbalu Konbulan, masyarakat memandang kalau yang pantas memandikan harus jiow atau muslim yang dianggap baik dalam pengamalan agama dan memahami cara mandi puasa Ramadan. Kata Bapak Djamin:

"Kalau di sini, yang memandikan itu harus pegawai syara, harus jiow, yang memahami urusan itu (cara mandi puasa Ramadan). Sebab, kadang kala, (meski) dia jiow, tapi belum terlalu paham."

${ }^{75}$ Amabon, Mengenal Bolaang Mongondow, 70-71.

${ }^{76}$ Faisal Manoppo, Sejak Abad ke-16 Mata Air Ini Ditemukan di Kotamobagu, (Kotamobagu: Youtube, 2019), https://youtu.be/ V87e_ GoyVNg.

${ }^{77}$ Tungkagi, "Islam di Bolaang Mongondow Utara...", 495.

${ }^{78}$ Amabon, Mengenal Bolaang Mongondow, 42.

${ }^{79}$ Wawancara Dengan Jiow Desa Tabang, Djamin Mokodompit, Pada 20 Desember 2020 M, Tempat Kediamannya di Tabang. 
Selain itu, yang unik dari cara pelaksanaan Monginbalu Konbulan, masyarakat yang tidak sempat datang mandi massal akan meminta jiow membuatkan air yang dibacakan doa atau niat mandi puasa untuk dipakai mandi di rumah. Dalam tradisi Monginbalu Konbulan biasanya juga akan banyak perempuan yang melakukan keramas menggunakan minyak dari parutan kelapa yang diolah sedemikian, biasa disebut coho yang memiliki khasiat membuat rambut lebih hitam dan menghilangkan kutu rambut, kegiatan keramasnya biasa disebut bacoho atau togulu. Sebagian memandang kalau bacoho merupakan bagian dari prosesi Monginbalu Konbulan. Namun, sebenarnya bacoho bukanlah bagian dari pelaksanaan tradisi ini. Hal itu tidak lain hanya dianggap sebagai aktivitas keramas biasa layaknya orang yang memakai shampo, namun masyarakat menggunakan parutan kelapa dalam melakukannya. Bahkan sekarang sudah jarang juga ada orang yang masih melakukan coho atau togulu. ${ }^{80} \mathrm{Jadi}$, bacoho bukan merupakan bagian dari prosesi atau pelaksanaan Monginbalu Konbulan, sehingga bisa ada bisa tidak. Tak perlu dipermasalahkan ke tradisinya, sebab bukan bagian dari prosesi tradisi, hanya kebiasaan sebagian perempuan saja yang kebetulan ada di sungai lalu bacoho, yang sebenarnya itu juga bisa dilakukan di rumah.

Cara mandi massal dalam tradisi Monginbalu Konbulan hanya sekadar kena air yang disiram-siramkan oleh jiow. Sementara, untuk mandi membersihkan tubuh sepenuhnya itu nanti dilakukan di rumah. Hal ini sebagaimana yang dijelaskan oleh Bapak Nidin:

“...kami siramkan begitu, mereka balik (ke rumah) ulang mandi lagi, mandi biasa. Cuma itu mandi puasa sudah dimandikan (di waktu Monginbalu Konbulan).,

Masyarakat mandi massal dalam keadaan memakai pakaian utuh seperti biasa. Jadi tetap dalam keadaan menutup aurat.

\footnotetext{
${ }^{80}$ Wawancara Dengan Jiow Desa Tabang, Djamin Mokodompit, Pada 20 Desember 2020 M, Tempat Kediamannya di Tabang.

${ }^{81}$ Wawancara Dengan Jiow Desa Bangomolunow, Nidin Tolodo, Pada 20 Desember 2020 M, Tempat di Masjid Desa Bangomolunow.
} 
Sebab, prosesi mandi massal dalam Monginbalu Konbulan hanya sekadar kena air yang disiram-siramkan oleh jiow, bukan mandi membersihkan seluruh tubuh.

Tradisi Monginbalu Konbulan sudah sangat lama dilakukan oleh masyarakat muslim Bolaang Mongondow. Suku Mongondow menyambut datangnya Ramadan dengan membersihkan diri, mandi suci puasa Ramadan, sebab besok sudah akan melakukan puasa sebulan penuh di bulan Ramadan. Mandi Bulan juga menjadi penguat niat serta kesiapan dalam menyambut puasa Ramadan.

\section{Sejarah Munculnya Tradisi Monginbalu Konbulan}

Belum jelas kapan tepatnya tradisi Monginbalu Konbulan mulai dilakukan oleh masyarakat muslim Bolaang Mongondow. Namun, yang pasti, tradisi ini sudah sangat lama. Bisa jadi sudah mulai dilaksanakan pada masa-masa awal perkembangan Islam di Bolaang Mongondow, yang telah dijelaskan sebelumnya, yaitu sekitar abad ke-19 M. $^{82}$

Jika ditanya kapan tradisi ini mulai ada, Jiow-jiow hanya akan berkata kalau tradisi ini sudah sangat lama. Sebagaimana kata Bapak Djamin:

"Memang saya mulai tahu sejak dari orang-orang tua. Ratusan tahun itu (tradisi Monginbalu Konbulan) sudah ada. Kalau saya, masih dari kakek saya sudah jadi jiow, turun ke ayah saya juga jadi jiow." ${ }^{, 83}$

Bapak Djamin yang sudah sepuh coba mengatakan kalau tradisi ini sudah ada sejak dari orang tuanya bahkan sejak dari kakeknya menjadi jiow. Artinya, tradisi ini memang sudah sangat lama dilakukan oleh masyarakat muslim Bolaang Mongondow, khususnya di desanya, Kelurahan Tabang. Berdasarkan hal ini, dapat ditarik asumsi kalau tradisi Monginbalu Konbulan sudah dilakukan sejak lama bahkan sangat mungkin sudah berlangsung

\footnotetext{
${ }^{82}$ Lihat poin pembahasan Islam di Bolaang Mongondow.

${ }^{83}$ Wawancara Dengan Jiow Desa Tabang, Djamin Mokodompit, Pada 20 Desember 2020 M, Tempat Kediamannya di Tabang.
} 
dari masa-masa permulaan masifnya Islamisasi di Bolaang Mongondow yang terjadi sekitar abad ke-19 M.

Kalau dari penjelasan Bapak Nibin yang sudah jadi jiow di Bangomolunow selama puluhan tahun:

"Pokoknya, sejak kampung ini terbuka begitu terus (sudah mulai ada tradisi Monginbalu Konbulan), sejak (dari) jiow-jiow sebelumnya sudah jadi kebiasaan itu mandi bulan puasa." 84

Desa Bangomolunow dibentuk sejak tahun $1952 \mathrm{M}^{85}$ Sejak dari awal desa ini berdiri, masyarakat memang sudah mengenal tradisi Monginbalu Konbulan. Dalam masyarakat Bolaang Mongondow (suku Mongondow), dikenal istilah tanah totabuan desa, yang merupakan lahan kebutuhan masing-masing desa. Setiap desa memiliki totabuan-nya. Kemudian, totabuan kelak menjadi pedukuhan desa masing-masing, serta berkembang menjadi desa yang berdiri sendiri. ${ }^{86}$ Proses mentotabuan ini berperan terhadap difusi budaya masyarakat Bolaang Mongondow ke seluruh wilayah Bolaang Mongondow Raya. Dalam kasus Desa Bangomulunow, sebagaimana dijelaskan Bapak Nibin, tradisi Monginbalu Konbulan sudah ada sejak desa itu mulai terbentuk. Artinya, masyarakat suku Mongondow yang menempati pedukuhan desa yang kelak menjadi Desa Bangomolunow memang sudah mengenal tradisi ini. Sehingga tradisi ini sudah ada sejak awal mula desa tersebut. Sebagaimana diketahui kalau masyarakat Suku Mongondow di Desa Bangomolunow kebanyakan berasal dari-atau punya hubungan kerabat dengan-Desa Bilalang, ${ }^{87}$ sementara di Tuduaog-termasuk desa di bagian Bilalang-juga pernah ada tradisi Monginbalu Konbulan.

Contoh lain, kalau melihat di Desa Pinolosian yang awalnya merupakan totabuan dari Poyowa Kecil, ${ }^{88}$ juga terdapat tradisi Monginbalu Konbulan. Serta, Poyowa Kecil dulu juga ada

\footnotetext{
${ }^{84}$ Wawancara Dengan Jiow Desa Bangomolunow, Nidin Tolodo, Pada 20 Desember 2020 M, Tempat di Masjid Desa Bangomolunow.

${ }^{85}$ Anonymous, "Sejarah Desa," Sikeda Bangomolunow, n.d., sikeda.id/profil/sejarah/.

${ }^{86}$ Amabon, Mengenal Bolaang Mongondow, 151.

${ }^{87}$ Diskusi Dengan Iwi, Warga Desa Bangomolunow.

${ }^{88}$ Amabon, Mengenal Bolaang Mongondow, 152.
} 
tradisi ini, namun sekarang sudah tak lagi dilaksanakan. ${ }^{89}$ Dari sini, bisa menjawab kenapa tradisi Monginbalu Konbulan menyebar hampir di seluruh desa di Bolaang Mongondow Raya, sebab proses mentotabuan menjadi media dalam penyebaran tradisi ini.

Selain itu, lahirnya tradisi ini didorong dari kebutuhan masyarakat muslim Bolaang Mongondow yang ingin mandi puasa sebagai bagian upaya menyucikan serta memantapkan diri dalam persiapan menyambut puasa Ramadan. Namun, karena masyarakat umumnya tak tahu bagaimana cara mandi puasa Ramadan atau merasa diri belum pantas untuk melakukannya secara mandiri, maka dilakukanlah secara bersama-sama dengan dipimpin oleh jiow yang dipandang pantas memandikan puasa Ramadan. Sebagaimana penjelasan Bapak Nidin:

"Karena banyak masyarakat yang tidak tahu cara mandi puasa (Ramadan), sebab masyarakat yang masih awam. Jadi, kami yang buatkan air begitu (memandikan mandi puasa)., 90

Sebab mandi puasa Ramadan terpandang sebagai kebutuhan dalam menyiapkan diri menyambut Ramadan, maka para jiow pun sebagai orang yang paham cara mandi puasa memimpin masyarakat untuk dimandikan secara bersama-sama di sungai maupun kolam yang kondusif untuk pelaksanaannya.

Jiow sebagai orang yang paham agama dimintakan untuk memandikan secara massal masyarakat awam. Dalam hal ini, tercipta interaksi sosial, solidaritas, antara masyarakat awam dengan jiow selaku tokoh agama di kampung, yang kemudian memunculkan tradisi Monginbalu Konbulan. Sampai sekarang, tradisi ini masih terus dilaksanakan oleh masyarakat muslim Bolaang Mongondow.

\section{Nilai-nilai dalam Pelaksanaan Monginbalu Konbulan}

Sebagaimana telah dijelaskan bahwa Monginbalu Konbulan lahir atas jawaban dari kebutuhan masyarakat muslim

\footnotetext{
${ }^{89}$ Diskusi Dengan Ira, Warga Kelurahan Poyowa Kecil.

${ }^{90}$ Wawancara dengan Jiow Desa Bangomolunow, Nidin Tolodo, Pada 20 Desember 2020 M, Tempat di Masjid Desa Bangomolunow.
} 
Bolaang Mongondow sendiri. Dalam menyiapkan diri menyambut bulan suci Ramadan, masyarakat akan melakukan mandi puasa. Pada proses perjalanannya, tradisi ini tidak hanya sebagai rutinitas tahunan yang diadakan setiap memasuki Ramadan, melainkan menjadi tradisi yang sarat nilai. Adapun beberapa nilai dalam Monginbalu Konbulan adalah:

\section{Nilai kerukunan}

Masyarakat sangat antusias dalam pelaksanaan tradisi Monginbalu Konbulan. Ketika sore hari terakhir di bulan Syaban pasti sudah banyak orang yang berkumpul di sungai atau tempat pelaksanaan Mandi Bulan lainnya. Di Kelurahan Tabang, tradisi ini sempat terhenti selama kurang lebih 5 tahun. Para orang tua kampung, lembaga adat, termasuk pemerintah, meminta untuk dilaksanakan kembali. ${ }^{91}$ Pelaksanaan tradisi ini penting, sebab selain merupakan warisan budaya Islam juga dapat mempererat kerukunan antar masyarakat.

Di tahun 2020, tidak ada pelaksanaan mandi massal, sebab kondisi pandemi Covid-19. Himbauan dari pemerintah yang melarang kegiatan mengundang kerumunan menyebabkan tradisi mandi massal ini pun tidak dilaksanakan, karena termasuk aktivitas yang mengundang keramaian. Saat Monginbalu Konbulan tidak dilaksanakan, maka banyak masyarakat yang merasa janggal atau kurang enak hati. Biasanya Ramadan dengan ragam tradisi berkumpul bersama (salah satunya dalam Monginbalu Konbulan), namun tiba-tiba tidak demikian. ${ }^{92}$ Dalam hal ini, tanpa disadari, pelaksanaan tradisi Monginbalu Konbulan yang melibatkan aktivitas bersama telah memunculkan rasa kerukunan dalam masyarakat. Kenyataan itu semakin terasa saat pandemi terjadi dan segala tradisi atau kegiatan kumpul-kumpul yang melibatkan banyak orang dilarang. Dengan adanya Monginbalu Konbulan masyarakat muslim Bolaang Mongondow memiliki

${ }^{91}$ Wawancara dengan Jiow Desa Tabang, Djamin Mokodompit, Pada 20 Desember 2020 M, Tempat Kediamannya di Tabang.

${ }^{92}$ Wawancara dengan Jiow Desa Bangomolunow, Nidin Tolodo, Pada 20 Desember 2020 M, Tempat di Masjid Desa Bangomolunow. 
momen mempererat $u k h w a h$ Islamiyah sebelum memasuki puasa Ramadan.

\section{Nilai solidaritas}

Pelaksanaan tradisi Monginbalu Konbulan memunculkan pembagian peran dalam interaksi sosial antara masyarakat awam dengan para jiow selaku tokoh agama setempat. Mandi puasa dirasa penting dilakukan sebelum masuk Ramadan, sementara masyarakat banyak yang tidak tahu bagai-mana cara mandi puasa atau merasa diri belum pantas untuk melakukannya secara mandiri. Keadaan masyarakat awam Bolaang Mongondow tersebut selaras dengan apa yang digambarkan Seven Kosel: "The group of people (of Bolaang Mongondow) tended to see themselves as non-experts who upheld certain parts of the tradition...." 93 Sehingga, para jiow sebagai orang yang paham cara mandi puasa memimpin masya-rakat untuk dimandikan secara bersama-sama. ${ }^{94}$ Dalam hal ini, muncul interaksi sosial yang melahirkan solidaritas antara masyarakat dengan jiow selaku tokoh agama.

\section{Nilai akidah}

Bagi masyarakat muslim Bolaang Mongondow tradisi Monginbalu Konbulan urgen dilakukan, serta tidak melanggar agama dalam arti tidak ada aktivitas yang mengarah pada menyekutukan Tuhan di dalamnya. ${ }^{95}$ Bahkan dalam pemaknaannya tradisi ini justru membesarkan Tuhan. Sebagaimana penjelasan Bapak Djamin:

"(meski) cuma tradisi, tapi kalau saya melihat itu (tradisi Monginbalu Konbulan) juga akan membesarkan Allah, bahwa Tuhan-nya bulan dengan kita itu satu. Maka dengan berkahnya

${ }^{93}$ Kosel, "The History...", 51.

${ }^{94}$ Wawancara dengan Jiow Desa Bangomolunow, Nidin Tolodo, Pada 20 Desember 2020 M, Tempat di Masjid Desa Bangomolunow.

${ }^{95}$ Wawancara dengan Jiow Desa Tabang, Djamin Mokodompit, Pada 20 Desember 2020 M, Tempat Kediamannya di Tabang. 
bulan ini (Ramadan), Allah berikan kesehatan, kekuatan, umur yang bermanfaat." 96

Pelaksanaan tradisi Monginbalu Konbulan mengingatkan pada hal yang sangat mendasar, bahwa bertemu dengan bulan Ramadan adalah nikmat besar dari Tuhan yang Maha Kasih. Sehingga, harus disyukuri. Pemaknaan ini menjadi satu aspek nilai akidah yang terkandung dalam tradisi ini.

\section{Nilai tradisi}

Sudah sejak lama mandi massal menyambut puasa Ramadan dilakukan oleh masyarakat muslim Bolaang Mongondow. Saking lamanya kebiasaan ini sampai-sampai para orang tua kampung tidak tahu jelas kapan awal mulanya. ${ }^{97}$ Dan, karena telah dilakukan turun-temurun maka Monginbalu Konbulan pun telah menjadi tradisi bagi masyarakat muslim Bolaang Mongondow. Artinya, pelaksanaan tradisi ini merupakan salah satu kekhasan masyarakat muslim Bolaang Mongondow dalam menyambut puasa Ramadan. Sehingga, urgen untuk terus dilestarikan.

Selain keempat nilai tersebut, Monginbalu Konbulan juga menjadi bagian dari upaya menyucikan diri sebelum masuk puasa Ramadan. Secara tidak langsung tradisi ini meneguhkan niat atau memantapkan kesiapan diri dalam menyambut puasa Ramadan. Banyaknya nilai dalam pelaksanaan tradisi Monginbalu Konbulan menjadikan tradisi ini pantas untuk terus dilestarikan sebagai bagian dari kekayaan tradisi Islam di Nusantara.

\section{PENUTUP}

Monginbalu Konbulan merupakan tradisi mandi puasa secara massal yang dilakukan oleh masyarakat muslim Bolaang Mongondow dalam menyambut puasa Ramadan. Dalam praktiknya tradisi ini dilaksanakan pada sore terakhir bulan Syaban atau

\footnotetext{
${ }^{96}$ Wawancara Dengan Jiow Desa Tabang, Djamin Mokodompit, Pada 20 Desember 2020 M, Tempat Kediamannya di Tabang.

${ }^{97}$ Ini tergambar dari wawancara peneliti dengan para jiow yang setiap ditanya: kapan tradisi ini mulai dilakukan? Jawabannya selalu sama: sudah lama sekali, masih dari orang tua hingga kakek-kakek kami memang telah mengenal tradisi Monginbalu Konbulan.
} 
sudah akan masuk malam pertama Ramadan. Seorang jiow yang memimpin prosesi mandi massal akan menyiramkan air ke orang-orang. Mandi dalam tradisi ini sekadar kena cipratan air tersebut, sehingga masyarakat melakukan tradisi mandi massal tetap dengan berpakaian menutupi aurat.

Belum ada kejelasan sejarah kapan tepatnya tradisi Monginbalu Konbulan mulai dipraktek oleh masyarakat muslim Bolaang Mongondow. Namun, mengingat dari narasi yang disampaikan para jiow bahwa tradisi ini sudah sangat lama dilakukan, sehingga bisa ditarik asumsi adalah sudah dimulai di masa masyarakat Bolaang Mongondow menerima Islam pada akhir abad ke-19 M. Lahirnya tradisi ini sebab dari kebutuhan masyarakat sendiri yang ingin mandi puasa Ramadan, namun karena umumnya masyarakat tidak tahu bagaimana caranya atau sudah tahu tapi merasa belum pantas mandi Ramadan sendiri, maka masyarakat pun dimandikan puasa Ramadan secara massal oleh jiow sebagai tokoh agama di kampung. Dan, proses mentotabuan termasuk media dalam penyebaran tradisi ini di desadesa Bolaang Mongondow Raya.

Tradisi Monginbalu Konbulan tidak hanya sebagai rutinitas tahunan yang diadakan setiap memasuki Ramadan, melainkan merupakan tradisi yang sarat nilai bagi masyarakat muslim Bolaang Mongondow. Adapun beberapa nilai dalam pelaksanaan Monginbalu Konbulan adalah nilai kerukunan, nilai solidaritas, nilai akidah, dan nilai tradisi. Selain itu, Monginbalu Konbulan merupakan upaya menyucikan diri sebelum masuk puasa Ramadan yang secara tidak langsung meneguhkan niat atau memantapkan kesiapan diri dalam menyambut puasa Ramadan. Banyaknya nilai dalam pelaksanaan tradisi Monginbalu Konbulan menjadikan tradisi ini pantas untuk terus dilestarikan sebagai bagian dari kekayaan tradisi Islam Nusantara dalam masyarakat muslim Bolaang Mongondow. 


\section{DAFTAR PUSTAKA}

\section{Buku}

Abdurrahman, Dudung. Metodologi Peneletian Sejarah Islam. Yogyakarta: Ombak, 2011.

Amabon, Litbang. Mengenal Bolaang Mongondow: Sejarah, Adat, Dan Budaya. Kotamobagu: Sembilan Bintang, 2018.

Lopez, Ariel C. "Conversion and Colonialism: Islam and Christianity in North Sulawesi, c. 1700-1900." Leiden University, 2018.

Malau, Dewi Lismaria. "Tradisi Mandi Pangir Pada Perempuan Etnis Jawa Dalam Menyambut Bulan Ramadahn Di Desa Pangarungan Kec. Torgamba Kota Pinang." Universitas Negeri Medan, 2018.

Manoppo, Hamri, Donald Qomaldiansyah Tungkagi, Almunauwar Rusli, Masmedia Pinem, dan Nurman Kholis. Dinamika Islamisasi Di Bolaang Mongondow Raya Sulawesi Utara, Abad Ke-17-20. Jakarta: Litbangdiklat Press, 2020.

Sjamsuddin, Helius. Metodologi Sejarah. Yogyakarta: Ombak, 2007.

Soehadha, Moh. Fakta Dan Tanda Agama: Suatu Tinjauan Sosio-Antropologi. Yogyakarta: Diandra Pustaka Indonesia, 2014.

Ulum, Amirul. Al-Jawi Al-Makki: Kiprah Ulama Nusantara Di Haramain. Yogyakarta: Global Press, 2019.

\section{Jurnal Ilmiah}

Abdurrahman, M. Kasim. “Arsitektur Masjid Jami'Sultan Ayyub Sanggau.” Jurnal Lektur Keagamaan 12, No. 1 (2014).

Ahsubli, Muhammad. "Ritual Budaya Mandi Safar Di Desa Tanjung Punak Pulau Rupat Kabupaten Bengkalis Provinsi 
Riau.” Jurnal Aqlam 3, No. 1 (2018).

Almu'tashim, Amru, dan Jerry Hendrajaya. "Tradisi Selamatan

Kematian Nyatus Nyewu: Implikasi Nilai Pluralisme Islam Jawa." Jurnal Lektur Keagamaan 17, No. 2 (2019).

Amaliyah, Efa Ida. "Nilai-Nilai Kearifan Dalam Tradisi Perang

Obor Di Tegalsambi-Jepara Sebagai Karakteristik Islam Nusantara." Jurnal Lektur Keagamaan 16, No. 2 (2014).

Dunnebier, William. "Over de Vorsten van Bolaang Mongondow." Bijdragen Tot de Taal-, Land-En Volkenkunde 105, No. 1 (1949).

Hastuti, Diah Retno Dwi, M. Saleh Ali, Eymal B. Demmallino, dan Rahmadanih. "Emile Durkheim (1858-1917)." Dalam Ringkasan Kumpulan Mazhab Teori Sosial (Biografi, Sejarah, Teori, Dan Kritikan), diedit oleh Zaiful, 1st ed. Pustaka Taman Ilmu, 2018.

Iswanto, Agus. "Keraton Yogyakarta Dan Praktik Literasi Budaya Keagamaan Melalui Media Digital." Jurnal Lektur Keagamaan 17, No. 2 (2019).

Kiptiyah, Siti Mariatul. "Tradisi Penulisan Tafsir Al-Qur'an Bahasa Jawa.” Jurnal Lektur Keagamaan 15, No. 2 (2017).

Kosel, Seven. "Chistian Mission in an Islamic Environment: Religious Conversion in North Sulawesi in the Light of a Case-Study from Bolaang Mongondow." Paideuma 51 (2005).

. "The History of Islam in Bolaang Mongondow, North Sulawesi." Indonesi and the Malay World 38, No. 110 (2010).

Napsiah. "Ngeloop Haga Puasa: Praktik Sosial Budaya Menyambut Ramadan Untuk Penguatan Identitas Muslim." Society 8, No. 1 (2020).

Pebrianto, Razali, Heri Saputra, dan Nurhasanah Bakhtiar. "Kearifan Lokal Dalam Tradisi Mandi Balimau Kasai: Peran Pemangku Adat Untuk Menjaga Nilai-Nilai Islam Di Desa 
Alam Panjang Kec. Rumbio Jaya Kab. Kampar Prov. Riau.” JUSPI (Jurnal Sejarah Peradaban Islam) 3, No. 1 (2019).

Rokhzi, Mokh. Fatkhur. "Pendekatan Sejarah Dalam Studi Islam.” Jurnal Modeling 3, No. 1 (2015).

Siswayanti, Novita. "Akulturasi Budaya Pada Arsitektur Masjid Sunan Giri.” Jurnal Lektur Keagamaan 14, No. 2 (2016).

Stickings, Jeremy. "Bolaang-Mongondow: Some Notes on History and Adat." Indonesia Circle. School of Oriental and African Studies. Newsletter 7, No. 18 (1979).

Tungkagi, Donald Qomaldiansyah. "Islam Di Bolaang Mongondow Utara, Sulawesi Utara: Dinamika Islamisasi Di Kerajaan Kaidipang Besar Dan Bintauna Abad Ke-7-19 M." Jurnal Lektur Keagamaan 17, No. 2 (2019).

_. "Varian Islam Nusantara: Jawa, Minangkabau Dan Gorontalo." Jurnal Lektur Keagamaan 15, No. 2 (2017).

Yusuf, Choirul Fuad. "Kesultanan Nusantara Dan Faham Keagamaan Moderat di Indonesia." Jurnal Lektur Keagamaan 14, No. 2 (2016).

\section{Website}

Abdul, Moh. Rivaldi. "Awal Mula Kehadiran Islam Di Bolaang Mongondow.” Alif.id, 2021. https://alif.id/read/moh-rivaldiabdul/awal-mula-kehadiran-islam-di-bolaang-mongondowb237006p/.

. "Sejarah Islam Di Bolaang Mongondow: Sultan Jakobus Manuel Manoppo Dan Keislamannya." Iqra.id, 2021. https://iqra.id/sejarah-islam-di-bolaang-mongondow-sultanjakobus-manuel-manoppo-dan-keislamannya-234423/.

. "Tradisi Mintahang (Doa Arwah) Dan Kepercayaan Tradisional Bolaang Mongondow." Harakah.id, 2021. https://harakah.id/tradisi-mintahang-doa-arwah-dankepercayaan-tradisional-bolaang-mongondow/. 
Anonymous. "Sejarah Desa." Sikeda Bangomolunow, n.d. sikeda.id/profil/sejarah/.

Manoppo, Faisal. Sejak Abad Ke-16 Mata Air Ini Ditemukan Di Kotamobagu. Kotamobagu: Youtube, 2019. https://youtu.be/ V87e_GoyVNg.

Redaksi. "Mandi Suci Sambut Ramadhan.” NU Online, 2008. https://www.nu.or.id/post/read/13570/mandi-suci-sambutramadhan. 


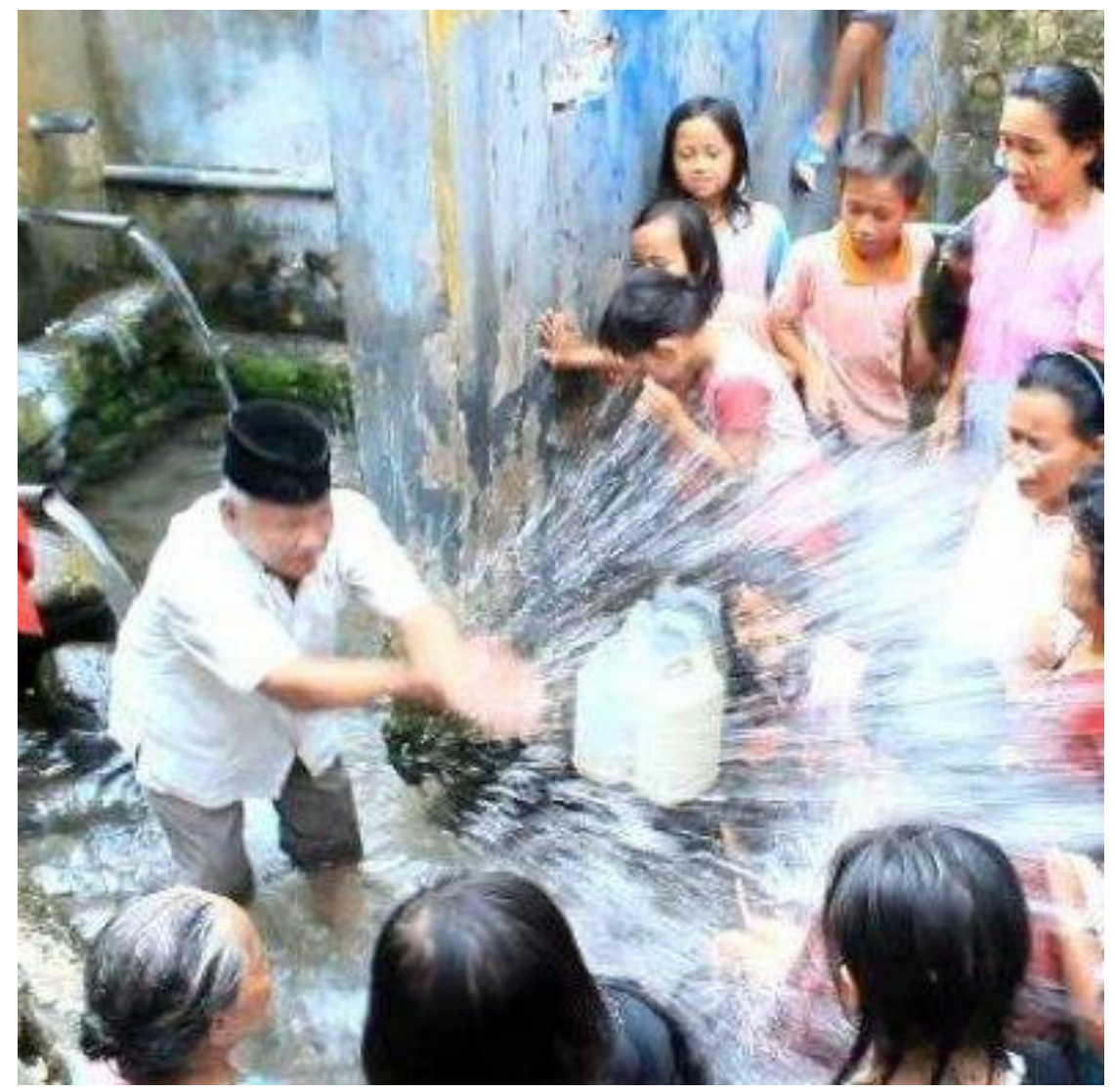

Sumber: https://manado.tribunnews.com/2019/05/06/ Gambar 1.

Tradisi Mandi Bersih Menjelang Puasa di Masyarakat Muslim Bolaang Mongondow 